
NCOMMUNITYFLEXIBILITY RESPONSIBILITYOPPORTU NITIESSAFETYORDERSPRIV ATEFINANCEINITIATIVETRA DITIONWELFAREREFORMCI TIZENSHIPNEO-LIBERALIS MEMPOWERMENTPARTICI PATIONVALUESMODERNGL OBALISATIONINCLUSIONC OMMUNITYFLEXIBILITYRES PONSIBILITYOPPORTUNITI ESSAFETYORDERSPRIVATE FINANCEINITIATIVETRADIT IONWELFAREREFORMCITIZ ENSHIPNEO-LIBERALISME MPOWERMENTPARTICIPAT IONVALUESMODERNGLOB ALISATIONINCLUSIONCOM MUNITYFLEXIBILITYRESPO NSIBILITYOPPORTUNITIESS AFETYORDERSPRIVATEFIN ANCEINITIATIVETRADITION WELFAREREFORMCITIZENS HIPNEO-LIBERALISMEMPO WERMENTPARTICIPATIONV ALUESMODERNGLOBALISA TIONINCLUSIONCOMMUNI TYFLEXIBILITYRESPONSIBI LITYOPPORTUNITIESSAFET YORDERSPRIVATEFINANCE INITIATIVETRADITIONWELF AREREFORMCITIZENSHIPN EO-LIBERALISMEMPOWER MENTPARTICIPATIONVALU ESMODERNGLOBALISATIO NINCLUSIONCOMMUNITYF LEXIBILITYRESPONSIBILITY OPPORTUNITIESSAFETYOR DERSPRIVATEFINANCEINITI A REFORMCITIZENSHIPNEO-L IBERALISMEMPOWERMENT PARTICIPATIONVALUESMO

The

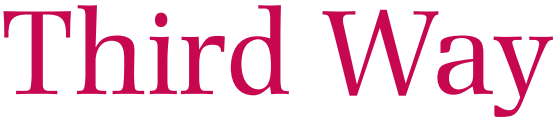

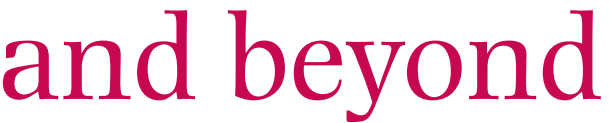

Criticisms, futures

and alternatives

EDITED BY

SARAH HALE

WILL LEGGETT

AND

LUKE MARTELL 


\section{The Third Way and beyond}

Published in our centenary year

$\approx 2004 \cong$ MANCHESTER UNIVERSITY PRESS 
Sarah Hale, Will Leggett, and Luke Martell - 9781526137883 Downloaded from manchesterhive.com at 04/26/2023 01:01:06PM 


\title{
The Third Way and beyond
}

Criticisms, futures, alternatives

\author{
edited by Sarah Hale, Will Leggett \\ and Luke Martell
}

Manchester University Press

Manchester 
Copyright (C) Manchester University Press 2004

While copyright in the volume as a whole is vested in Manchester University Press, copyright in individual chapters belongs to their respective authors.

This electronic version has been made freely available under a Creative Commons (CC-BY-NC$\mathrm{ND}$ ) licence, which permits non-commercial use, distribution and reproduction provided the author(s) and Manchester University Press are fully cited and no modifications or adaptations are made. Details of the licence can be viewed at https://creativecommons.org/licenses/by-nc-nd/3.0/

Published by Manchester University Press

Altrincham Street, Manchester M1 7JA

www.manchesteruniversitypress.co.uk

British Library Cataloguing-in-Publication Data

A catalogue record for this book is available from the British Library

Library of Congress Cataloging-in-Publication Data applied for

ISBN 0719065984 hardback

0719065992 paperback

First published 2004

1110090807060504

10987654321

The publisher has no responsibility for the persistence or accuracy of URLs for any external or third-party internet websites referred to in this book, and does not guarantee that any content on such websites is, or will remain, accurate or appropriate.

Typeset in Sabon with Gill Sans display by Servis Filmsetting Ltd, Manchester 